IZA DP No. 8881

International Migration Opportunities and Occupational Choice: A Case Study of Philippine Nurses 2002 to 2014

Mary Arends-Kuenning Alvaro Calara Stella Go

February 2015 


\title{
International Migration Opportunities and Occupational Choice: A Case Study of Philippine Nurses 2002 to 2014
}

\author{
Mary Arends-Kuenning \\ University of Illinois and IZA \\ Alvaro Calara \\ Independent Researcher, Philippines \\ Stella Go \\ De La Salle University, Philippines
}

Discussion Paper No. 8881

February 2015

\author{
IZA \\ P.O. Box 7240 \\ 53072 Bonn \\ Germany \\ Phone: +49-228-3894-0 \\ Fax: +49-228-3894-180 \\ E-mail: iza@iza.org
}

\begin{abstract}
Any opinions expressed here are those of the author(s) and not those of IZA. Research published in this series may include views on policy, but the institute itself takes no institutional policy positions. The IZA research network is committed to the IZA Guiding Principles of Research Integrity.

The Institute for the Study of Labor (IZA) in Bonn is a local and virtual international research center and a place of communication between science, politics and business. IZA is an independent nonprofit organization supported by Deutsche Post Foundation. The center is associated with the University of Bonn and offers a stimulating research environment through its international network, workshops and conferences, data service, project support, research visits and doctoral program. IZA engages in (i) original and internationally competitive research in all fields of labor economics, (ii) development of policy concepts, and (iii) dissemination of research results and concepts to the interested public.
\end{abstract}

IZA Discussion Papers often represent preliminary work and are circulated to encourage discussion. Citation of such a paper should account for its provisional character. A revised version may be available directly from the author. 


\section{ABSTRACT}

\section{International Migration Opportunities and Occupational Choice: A Case Study of Philippine Nurses 2002 to 2014*}

We analyze trends in nursing education in the Philippines during a period of rising and falling demand for Philippine nurses in the developed countries. Based on focus group discussion data obtained in the Philippines, we examine students' motivations to become nurses and to what extent their choices were affected by the possibility of international migration. The number of nursing graduates rose, resulting in brain gain. However, policies promoting the migration of skilled workers such as nurses impose high costs on middle class and lower class families who invest in education hoping that a family member will be able to migrate.

JEL Classification: F66, I11, J24, J44

Keywords: brain drain, brain gain, international nurse migration, Philippines

Corresponding author:

Mary Arends-Kuenning

Department of Agricultural and Consumer Economics

University of Illinois

408 Mumford Hall, MC-710

1301 W. Gregory

Urbana, IL 61801

USA

E-mail: marends@illinois.edu

\footnotetext{
* The authors would like to thank Ilana Akresh, Cindy Buckley, Jeffrey Groen, Tim Liao, Monica McDermott, Noreen Sugrue, Karen Tabb, and other members of the Demography Group at the University of Illinois for their helpful comments and suggestions.
} 


\section{Introduction}

With globalization, the migration of health care workers from developing countries to developed countries accelerated, leading to renewed concern in the mid2000s about brain drain. Nurses and doctors who trained in developing countries, often at public expense, were recruited by hospitals and health care systems in developed countries. In the late 1990s, some economists took a skeptical view of the concerns about brain drain, arguing that the possibility of migrating to a high-paying job in a developed country might provide incentives for individuals in developing countries to acquire more education than they would in the absence of migration. These arguments were revisited by Docquier and Rapoport (2012) in a review article and by a series of case studies (Batista, Lacuesta, and Vicente 2012, Gibson and McKenzie 2011, Chand and Clemens 2008).

Brain gain is presented as a positive outcome for developing countries, because the stock of human capital increases as people gain more education. The concept of brain gain is problematic because it occurs when people invest in education because they wish to migrate, but then they are not able to do so. Advocating for brain gain overlooks the costs to middle class and lower class families who invest in education in the hopes that a family member will be able to migrate. We illustrate this point through examining nurse education in the Philippines from the mid-2000s to the early 2010s.

We argue that a brain gain occurred with respect to the quantity of Philippine nurses in the late 2000s and early 2010s. Nursing school enrollments increased due to increased opportunities to migrate. The Philippines was well positioned to respond to increased demand for nurses. Philippine nurse migration to the United States had a long 
history, achieving a significant scale by the 1960s (Brush 2010). The nursing educational system was designed to meet international nursing standards. The sector expanded rapidly in the mid-2000s with established programs increasing their enrollments and the opening of new nursing programs. Most of the nursing colleges were in the private sector and charged relatively high tuition rates. Therefore, emigration of Philippine nurses did not entail the loss of skilled personnel whose educations were financed with public funds.

The brain gain that the Philippines experienced came at a human cost, which has been overlooked in the literature. The demand for international workers is typically for a specific skill such as nursing, rather than a general qualification, such as a university degree. A nursing student invests in a specific set of skills, many of which might not be useful in a profession outside of nursing. The economic models in which brain gain occurs require that not all who wish to migrate abroad will be able to do so (Commander, Kangasniemi, and Winters 2004). Families might overestimate their members' chances of being able to successfully complete a degree program and migrate to a high-paying job abroad. In the case of the Philippines, increased demand for a nursing degree led to the expansion of low-quality, but expensive, nursing schools in the 2000s. As a result, pass rates on the national nursing license exam declined. For those who passed the exam, when international demand for nurses fell rapidly in 2007-08, the supply of nurses exceeded the demand. Because hospitals in developed countries typically required 1 to 2 years of tertiary hospital experience, and the supply of nurses was high, Philippine nurses worked as volunteers in Philippine hospitals, and, in some cases, paid the hospitals to work there. 
To examine the response of the Philippine nursing education sector to international demand, we analyzed quantitative and qualitative data. Quantitative data were compiled from national statistics. We show that nursing school enrollments and the number of nursing graduates rose rapidly in response to perceived migration opportunities. When demand for nurses in developed countries fell, adjustment took several years, resulting in a surplus of nurses. To examine the extent to which nursing students decided to become nurses because of the possibility of migrating to a developed country, we conducted 8 focus groups with Philippine nursing students in 4 nursing schools and universities that varied in admissions selectivity and graduates' performance on the nursing licensure exam.

\section{Brain Drain and Brain Gain}

In the early 2010s, researchers showed a renewed interest in the possibility that international migration of highly educated workers would lead to a brain gain rather than a brain drain. For example, a 2011 issue of the Journal of Development Economics was devoted to this topic. This positive outcome occurs if people choose to increase their schooling because of the possibility that they will be able to migrate to a developed country (Marchiori, Shen, and Docquier 2013). Commander, Kangasniemi, and Winters (2004) developed a model of brain gain, which only occurs when potential employers in the host countries are not able to screen the quality of applicants in the source country. Those in the source country who are on the margin of deciding whether to obtain training in the occupation must perceive that there is a chance that they will be chosen to migrate. If host country employers only take the top quality employees in the source country, and employers and employees know employees' quality, then incentives are not changed at 
the margin. In the case of Philippine nurses, employers were able to screen for quality through the various exams that international nurses must take to be eligible for employment in developed countries. The rankings of nursing schools were publicized and well known. However, we show with the focus-group data that nursing students were optimistic that they would be chosen to migrate, despite having information that nurse migration rates had fallen and regardless of their schools’ ranking.

Schiff (2006) was pessimistic about the possibility of brain gain for reasons that were relevant for the case of Philippine nurses. First, workers vary in skill, and the most skilled are the most likely to migrate. The country may gain educated workers, but the "best and the brightest” leave. More people are educated as nurses, but the average quality of nurses falls as the best qualified emigrate. Second, prospects for emigration are uncertain and depend on the vagaries of developed countries' immigration policies. Students who are risk averse will prefer more certain employment to risky employment. A tension exists within the models because brain gain is more likely when the probability of migration is relatively low, but the lower the probability, the more risky the education investment and the less likely that people are to choose it. In a dynamic model, a brain gain cannot persist because the net brain grain is equal to zero in a steady state. Adjustment follows a cobweb model, and delays result as the supply of educated labor responds to demand. A temporary brain gain occurs, which dissipates as fewer students decide to invest in education to migrate.

Recent empirical work suggested that brain gain occurred in favorable contexts. In a cross-country study, Docquier, Lohest and Marfouk (2007) found that brain drain was more likely to occur when countries were small, located close to an OECD country, 
had a high migration rate for educated labor, and had great disparities in educational levels across the population. These conditions did not prevail in the Philippines, which was a large country and was not close to OECD countries, except for Australia, Japan, and New Zealand. Although it was the second-largest source country for skilled migration, it did not rank in the top thirty countries with populations above 5 million for rate of skilled emigration (Docquier and Marfouk 2005). Emigration streams were dominated by skilled labor, comprising 67 percent of the total number of emigrants, with the Philippines ranking fifth on the list of countries with the highest selection rates (Docquier and Marfouk 2005). Relative to other developing countries, inequality in educational levels was low and had been decreasing. ${ }^{2}$ In another cross-country study, Beine, Docquier, and Rapoport (2008) concluded that the Philippines experienced a slight brain gain between 1990 and 2000. They compared the migration that occurred with a counterfactual where skilled emigration rates were equal to unskilled emigration rates. These studies looked at brain drain and brain gain at the country level. However, looking at the big picture missed the details that complicate the simple, binary brain drain/brain gain story.

Country case studies in Cape Verde (Batista, Lacuesta, and Vicente 2011) and in Fiji (Chand and Clemens 2008) found that migration prospects led to higher levels of educational attainment. In the case of Cape Verde, an increase in the probability of one's own future migration of 10 percent led to a 4 percentage point increase in the probability that an individual completed intermediate secondary school. Unlike nursing education,

\footnotetext{
${ }^{2}$ In a list of 12 developing countries, the Philippines had the fourth-lowest Gini coefficient, 0.305 in 1995 (Lopez, Thomas, and Wang 1998). Mesa (2007) reports that the educational Gini coefficient fell to 0.236 by 2000 .
} 
secondary schooling is general and is the base for further educational investments and for success in a variety of jobs. The authors did not look at university-level education. Chand and Clemens (2008) compared educational levels of Indians in Fiji with Fijians. When a coup occurred that harmed the prospects of Indians in Fiji, the number of Indians with tertiary schooling increased, and the difference between Indians and Fijians increased. Not all the Indians with tertiary education could migrate. The difference between Indians and Fijians was greatest in colleges that trained students for occupations that were in demand abroad such as engineering, teaching, and business. Chand and Clemens did not look at skill mismatch within Fiji.

The case of Philippine nurses provides a case study to look at brain gain within a specific sector in detail. A brain gain did occur, but at considerable human costs. ${ }^{3}$ In addition, the brain gain in nursing was temporary. In 2008, although opportunities to migrate abroad were becoming restricted, nursing students persisted in believing that they had a possibility of migrating. The number of graduates from nursing schools fell, but more gradually than they had risen.

\section{Nursing education and licensing in the Philippines}

Philippine nursing education is oriented towards international markets. Because of the Philippines' history as a U.S. colony, instruction is in English. Most of the schools are private and, until recently, establishing a new school was easy. The Commission on Higher Education (CHEd) is responsible for certifying nursing programs. The Philippine government actively encouraged the expansion of nursing schools and of nurse migration

\footnotetext{
${ }^{3}$ Another cost of pro-nurse migration policies that we do not discuss in this paper is that the increased developed country demand for Philippine nurses created incentives for Philippine doctors to enroll in short courses to become nurses. See Lorenzo et al (2007), Lorenzo et al. (2012).
} 
starting in the 1960s. The number of schools increased from 17 to 140 between 1950 and 1970. Between 1965 and 1985, an estimated 25,000 Filipino nurses migrated to the United States (Choy (2003) as cited by Kingma (2006)). Another expansion in the number of nursing schools occurred between the late 1990s and early 2000s, and by 2006 there were about 460 nursing colleges, which graduated a total of 20,000 nurses each year (Lorenzo et al. 2007).

Figure 1 shows trends in enrollments and in the number of graduates for nursing and for medical and allied fields. For the most recent years, data were available for medical and allied fields, but not specifically for nursing. The graphs show that from 2000 to 2011, trends in medical and allied fields were driven by nursing enrollments; therefore the recent trends in the medical and allied fields represented what happened with nursing trends.

[Figure 1 about here]

Enrollments in nursing rose rapidly until 2006-07, when they started to fall. From 2000-01 to 2006-07, enrollments in nursing increased from 29,046 to 452,793 , an increase of 1,459 percent (Figure 1). To provide context, during the same period, general enrollments in universities rose steadily from 2,430,842 to 2,604,449, an increase of 7 percent. Nursing enrollments fell 8 percent between 2006-07 and 2007-08, a period when the media reported about the slowdown in nurse migration. At the same time, total enrollments in universities continued to increase by 2 percent. The number of nursing graduates increased faster than the number of enrolled students from 2000-01 to 2006-07, 
going from 4,409 to 79,149, an increase of 1,694 percent (Figure 1). ${ }^{4}$ During the same time period, the total number of university graduates increased from 363,640 to 444,427 , a 22 percent increase.

When the demand for immigrant nurses in developing countries fell, enrollments responded slowly, and the number of nursing graduates adjusted more slowly than enrollments did. Enrollment fell slightly from its 2006-07 peak in 2007-08 and fell again in 2008-09. In 2009-10, enrollment fell 17 percent from the previous year, and in 201011, 26 percent from the previous year. In 2010-11, enrollments were about equal to what they had been in 2004-05 (Figure 1). Looking at enrollment in medical and allied fields, enrollments continued to fall in 2011-12, 2012-13, and 2013-14, but then enrollments appeared to plateau at the same level as 2002-03 (Figure 1). These trends were likely to represent nursing trends. During this same period that nursing enrollments were falling, university enrollments increased by 13 percent.

Looking at graduates, the number of nursing graduates decreased in 2009-10 by 7 percent from its peak in 2008-09 (Figure 1). The number of university graduates increased by 3 percent between 2008-09 and 2009-10. The trends in the graduates in medical and allied fields between 2010 and 2013 showed a more dramatic decline than the trend for nursing graduates between 2008 and 2010 and suggested that the number of nursing graduates fell rapidly, as well. The number of graduates in medical and allied fields fell by 9.3 percent between 2008-09 and 2009-10, 11 percent between 2009-10 and 2010-11, 22 percent between 2010-11 and 2011-12, and 29 percent between 2011-12 and

\footnotetext{
${ }^{4}$ The nursing enrollment and graduation figures are from Lorenzo et al. (2012). The university enrollment and graduation figures are from the CHEd website (2012 and 2014).
} 
2012-13. The peak and subsequent decline in the number of graduates lagged the peak and decline in enrollments by two years (Figure 1).

After graduation, nursing students take the Philippine Nursing Licensure Exam, which is administered by the Professional Regulation Commission. The number of graduates taking the exam increased over time, although the opportunities for migrating to the United States and the U.K. decreased with the recession that started at the end of 2007. The number of test takers started to decrease with the test administrations in July 2010 and December 2010. Figure 2 shows the number of people who took the exam and the number who passed the exam from June 2006 until May 2014. The number taking the exam included those taking the exam for the first time as well as repeat exam takers. The number of newly licensed nurses reached a peak in November 2008 with approximately 40,000 new nurses. In the May 2014 test administration, 11,225 nurses passed (Professional Regulation Commission 2014).

[Figure 2 about here]

Over time, the pass rate on the exam fell, which led to concern among nursing leaders about the quality of nursing education. Rapid expansion of programs led to a decrease in the quality of student applicants as well as the quality of schooling. Figure 2 shows the pass rates between June 2006 and May 2014. Pass rates were about 50 percent in 2006, and they trended downward. Between 1999 and 2004, pass rates averaged about 50 percent (Professional Regulation Commission 2014). The pass rates were volatile after July 2011, with the pass rates for the December administrations being lower than those in June and July. For the December 2013 administration, pass rates reached a low of 31 percent. 
Nursing leaders attempted to regulate the quality of the nursing schools. During the 2000s, they were not able to shut down poorly performing schools. Politicians owned interests in nursing schools and were not interested in shutting them down (M. Lorenzo, personal communication, August 12, 2008 and K. Ronquillo, personal communication, July 31, 2008). In 2002, the CHEd, which certified nursing curriculum, issued a moratorium on new nursing schools, which was subsequently lifted. At the end of 2010, CHEd issued a new moratorium on nursing schools (Quismundo 2010). In 2011, CHEd issued a memorandum order that all B.S. nursing programs that had average passing rates of 30 percent and below for a three-year period starting in 2008 would be issued orders for immediate closure (CHEd 2011). A number of schools failed to produce even one graduate in five years who had passed the exam (Alave 2009). CHEd's attempts to close low performing schools were routinely met with lawsuits. The Commission did not publicly reveal the names of schools that were to be closed (Pazzibugan 2013).

With the growth in nursing graduates and the restrictions to emigration, many Filipino nurses were not able to find paid jobs in the Philippines. In 2009, only 31,058 nursing positions were available in hospitals (Lorenzo et al. 2012) compared to more than 70,000 nurses who passed the licensure exam that year (Figure 2). To migrate to the U.S., at least 2 years of experience in a tertiary hospital were required. The increased supply of nurses led to a situation in which nurses worked as volunteers in hospitals to gain the necessary experience, and in some hospitals, nurses paid the hospitals to work there. Figure 3 shows trends in nursing wages in the private and public sectors in 2010 pesos. In the private sector, wages fell, whereas in the public sector, in which wages were set by law, wages rose. Newspaper and journal articles in the mid-2000s argued that the 
Philippines was becoming a country hit very hard by brain drain in health services. After 2008, nursing leaders described a situation with a glut of inexperienced nurses, but a shortage of experienced nurses, many of whom had migrated (L. Pacquiz, personal communication, July 15,2008$)$. The opportunity to migrate had encouraged many to increase their schooling and study nursing, but inexperienced nurses were not able to find nursing jobs and build careers.

[Figure 3 about here]

\section{Filipino nurse migration}

Most Filipino nurses were employed abroad. Lorenzo et al. (2007) reported that in 2003, 193,223 Filipino nurses were employed. Of these, 85 percent were working internationally. Approximately 30,000 nurses worked in the Philippines, with 65 percent working in the public sector, 28 percent working in the private sector, and 8 percent working in the educational sector.

Accurate annual migration statistics are difficult to put together. The Philippine Overseas Employment Administration has a mandate to maintain a registry of all overseas workers. However, the registry covers only temporary migration, and most nurses who migrate to the U.S. do so on a permanent basis. The Commission on Filipinos Overseas maintains statistics for Filipinos who plan to emigrate permanently on immigrant visas. Federal law requires that emigrants register with the Commission before they leave the Philippines (Lorenzo et al 2012). The data probably give an underestimate of the number of nurses who migrate. The U.S. government does not release detailed data about the source countries and occupations of visa holders. 
The volatility of both temporary and permanent nurse migration from the Philippines is shown in Figures 4 and 5. From 1997 to 2008, a total of 103,629 nurses left the Philippines as temporary workers and 24,472 nurses left the Philippines as permanent workers (Lorenzo et al. 2012). Figure 4 shows that temporary migration to Saudi Arabia increased over time whereas temporary migration to the U.S. and to the U.K. spiked and fell (Lorenzo et al. 2012, POEA 2014). By 2010, Saudi Arabia was the most important destination country for temporary nurse migration with 8,513 migrants, accounting for 70 percent of migrants. The second most important destination country was Singapore, with 722 temporary nurse migrants. In 2005, almost 4,000 Philippine nurses entered the U.S. temporarily, but then in the following year, only 202 nurses entered temporarily. Temporary nurse migration to the U.K. peaked at 5,383 nurses in 2001, but then fell to only 28 nurses in 2008.

[Figure 4 about here]

[Figure 5 about here]

For permanent nurse migration, the U.S. was the dominant destination country for Philippine nurses (Figure 5). At the peak in 2006, 5,790 nurses migrated permanently to the U.S., but the number fell to 1,107 in 2007 as U.S. visas became less available to Filipino nurses (Lorenzo et al. 2012).

One pull factor for migration is the difference in wages for nurses between source countries and destination countries. In 2008, the median annual income for a nurse was \$US 62,450 in the United States (U.S. Bureau of Labor Statistics 2014). In the Philippines in 2008, the annual salary for a nurse was equivalent to \$US 1,813 per year in the private sector and \$US 2,042 in the public sector (Bureau of Labor and Employment 
Statistics, Republic of the Philippines 2013). In the UK, registered nurses in hospitals made the equivalent of $\$$ US 48,512 per year on average (OECD 2014). In Saudi Arabia, the beginning salary was about $\$ 20,000$ to $\$ 24,000$ per year (Lorenzo, et al. 2012, p. 169)..$^{5}$

\section{Obstacles to migration}

The migration process takes years and involves many screening procedures. After graduating from a CHEd- approved program, nursing graduates must first pass the Philippine Nursing Licensure Exam. In June 2008, when our qualitative data were collected, the pass rate was 43 percent (PRC 2008). From that point, obtaining a position in a tertiary hospital is desirable, as many hospitals in developed countries require 2 years of experience at this level.

To migrate to the United States, nurses must obtain a visa. U.S. employers bring Filipino nurses into the United States either under a temporary, H-1B visa or under a permanent, EB-3 visa. Most nurses arrive in the U.S. with permanent EB-3 visas. Before applying for EB-3 or H-1B visas, foreign-trained nurses must meet strict requirements. The US Congress established the US Commission on Graduates of Foreign Nursing Schools (CGFNS) to certify that the post-secondary education of foreign-trained nurses seeking U.S. visas meets U.S. standards. Applicants must pass an English proficiency test and the National Council Licensure Examination (NCLEX), which all U.S. RNs must pass to obtain a nursing license (Aiken et al. 2004).

\footnotetext{
${ }^{5}$ A 2014 recruitment notice for 200 Philippine ICU nurses to work in Riyadh offered a salary equivalent to about \$US 920 per month. In addition, nurses would receive free food and accommodation. http://www.poea.gov.ph/gpb/RSF\%20140031.pdf
} 
Once employers have filed an application for the visa on behalf of a nurse, she must wait for the visa to be issued. The wait times vary and are unpredictable. The U.S. issues only a certain number of EB-3 visas worldwide each year, available for skilled occupations including nursing. When the visas run out, the applicants in the queue are carried over until the next year. The wait times varied dramatically during the 2000s. In 2005, the U.S. earmarked 50,000 additional EB-3 visas for nurses (Tsitouras and Lopez 2009). The U.S. consulate in the Philippines processed visa applications soon after employers filed them, and wait times were very short until the 50,000 visas were all allocated by the end of 2006. To contrast, in 2008, the U.S. issued a total of 166,511 EB3 visas for all skilled workers from all countries (U.S. Department of Homeland Security 2009), and the wait time for EB-3 visas for Filipinos was 3.5 years, as the consulate was issuing visas for applications filed in May 2005 (U.S. Department of State 2008). In the meantime, nurses who were waiting were required by their employers to remain working to maintain their skills.

Agencies emerged to recruit nurses for hospitals abroad. Some of these agencies were unscrupulous and took fees from nurses eager to work abroad. Others were legitimate. An agent we interviewed who worked to recruit nurses for a prominent hospital in the U.S. reported that he had been recruiting 100 nurses per year, but in 2008, he recruited about 70. He recruited nurses from the top nursing schools in the Philippines, from schools with pass rates of at least 80 percent. The agency had advertised, but switched to relying on referrals from nurses that had already been placed with the U.S. hospital (J. Ong, personal communication, August 2008). Nurses who attended lower quality schools would not have access to this pathway to employment in the U.S. 
To obtain work in the UK, no qualifying exam was required. Two years of work experience in the UK were required to apply as a nurse, and many Filipino nurses worked as nurses' aides. Nurses could bring their families to the UK after 2 years (Goode 2009). In the mid 2000s, the UK shifted its policy on nurse migration to favor applicants from Eastern European countries that were part of the European Union. In 2008, the UK removed the category of overseas qualified nurses and midwives from the list of skilled workers who could apply for a visa. Those nurses who had offers from UK employers could apply as sponsored skilled workers (Home Office UK Border Agency 2008). A 2010 newspaper article described a study-and-work program introduced in 2006 through which Filipino nurses could study in the U.K. for 9 months to 2 years while working 20 hours a week. This program became the most common way for nurses to migrate to the UK. A recruiter noted that "most Filipino nurses in the United Kingdom end up becoming caregivers, as the country is also suffering from a shortage of health workers" (Aning 2010). Therefore, migrating to the UK involved additional training, with uncertainty at the end of the training period as to the quality of the job.

Saudi Arabia did not issue immigrant visas (Goode 2009); all migration was temporary. As it became more difficult to migrate to the U.S., nurses chose to migrate to Singapore and Saudi Arabia instead. Migration to Saudi Arabia increased from 4,886 in 2005 to 9,965 in 2009 and 8,513 in 2010 (Philippine Overseas Employment Administration 2014). The growth in placements in Saudi Arabia was not enough to meet the demand from the Middle Eastern country (Uy 2008). A 2010 newspaper article stated that 5,000 jobs were available in the Middle East, but unemployed Filipino nurses were not willing to take them because of concerns about security (Philippine Daily 
Inquirer 2010). The focus groups we conducted provided some insights into why these jobs went unfilled, which will be discussed below.

Having discussed the general background and context of nursing education and nurse migration in the Philippines, we examine how nursing students perceive the global nursing labor market. We look at how the context affects their decisions and their strategies.

\section{Data}

We collected qualitative data through focus group discussions in order to examine the extent to which Filipino nursing students decided to become nurses because of the possibility of migration. The models of brain gain require that individuals invest in schooling because of migration incentives. We also explored students' perceptions of the migration process and of the quality of nursing schools. For brain gain to occur, students must perceive that they have a high probability of being able to migrate.

We prepared a series of questions to be applied in each focus group, which are available as Appendix A. Two of the authors conducted the focus groups in English, with the male author, a Filipino, interviewing the male students, and the first author, from the U.S.A, interviewing the female students. The focus groups were carried out as conversations, with the moderators steering the conversations to make sure each question was answered. The focus groups were recorded, after the participants signed a consent form.

We conducted 8 focus groups in 4 nursing schools. The focus groups were split by gender to examine gender differences in attitudes towards migration. Nursing remains a female-dominated profession in the Philippines, although the proportion of men has 
been increasing. A total of 43 students participated, and each focus group averaged 5 participants. Each participant was asked to complete a brief survey including questions about family background, expenses, relatives living abroad, and financing of nursing education. We chose the nursing schools by the following criteria: 1 . Schools that graduated at least 100 students per year; 2. Schools whose graduates presented outstanding performance, average performance, and below average performance on the nursing licensure exam; 3 . Schools that were accessible given the location of the research team and traffic conditions in Manila. Three schools were chosen that were located in metro Manila, and one was located in Tagbilaran, Bohol province in order to contrast the experience in the largest city with the experience in the provinces. We refer to the four schools as schools A, B, C, and P.

[Table 1 about here]

The schools varied in size, tuition, and pass rates (Table 1). Schools A and B had tuition that was 50 percent higher than the tuition in schools $\mathrm{C}$ and $\mathrm{P}$. The average overall pass rate for the nursing licensure exam was 43 percent in June 2008, so three of the four schools performed well above the average, with school C performing slightly below average (pass rates are calculated by combining data for the June 2008 and November 2008 test administrations). School A was one of the top nursing schools in the Philippines, with an almost perfect pass rate. School B had the largest graduating class and had scaled up its nursing programs throughout the early 2000s. School C experienced an overall pass rate of below 20 percent in June 2008, but improved to almost 50 percent in the November 2008 administration. Therefore, our focus groups occurred in schools that represented the higher end of quality of Philippine nursing schools. 
The focus groups were not a random sample of the Filipino nursing student population, but the transcripts provided themes that were consistent across focus groups, as well as consistent with interviews with nursing leaders and with previous research about nursing education in the Philippines. The nursing deans organized the focus groups for the research team. Typically, we visited a nursing school and interviewed a dean, and then we scheduled a time for the focus group discussions. The dean contacted the students and scheduled a time and location for the discussions. This procedure might cause concern because the deans might have chosen students who were likely to speak highly about their programs, or who were likely to migrate. We do not have evidence that the deans selected students for these reasons. Students were chosen for focus groups primarily based on their schedules. For example, if an afternoon meeting was convenient for the researchers, deans chose a class that got out just before the desired meeting time. The focus group discussions occurred within a few days after the interview with the dean, so deans did not have much time to select students. The maximum amount of time that elapsed between an interview and the focus group discussions was a week. In the focus group discussions, students often criticized their schools and their nursing programs, so they were not chosen to be students who would promote the schools. Students were provided with a light meal in exchange for their participation.

Although tuition appeared low by U.S. standards (Table 1), eight semesters of tuition in nursing college constituted a nontrivial investment in a country where the estimated Gross National Income per capita (PPP) in 2009 was $\$ 6,480$ (World Bank 2014). 


\section{Characteristics of Focus Group Participants}

Selected characteristics of the focus group participants are presented in Table 2. The sample mean age was 22.85 years, with a range from a minimum of 18 years to a maximum of 45 . The students in the sample came primarily from middle-class backgrounds, with 86 percent of the students' fathers and 84 percent of the students' mothers having at least a university education. Almost half of the students' fathers were in professional occupations. The sample was about evenly split between males and females, and only 9.3 percent were married.

[Table 2 about here]

Almost all of the participants wanted to migrate-88.1 percent. A very high percentage, 88.1 percent, had at least one relative who lived outside the Philippines, with 35 percent having a parent who lived outside the Philippines. About 14 percent of the students had lived abroad themselves. About a third of the participants had a relative who lived outside of the Philippines and was working as a nurse, indicating strong family ties to international nursing.

The U.S. was the top choice as a migration destination among those who intended to migrate, with 63 percent giving this choice. The next most popular country was Canada, with 24 percent of the respondents. Fewer students gave the UK and New Zealand as their top choices.

Students’ nursing education was primarily financed by family members. Students reported 59 percent of the time that parents were financing their studies. Siblings financed the students' education for 21 percent of the sample. An equal percentage of respondents (15 percent) answered that they were funding their education that answered 
that other extended family members (aunts, uncles, grandparents) were funding their education.

The survey revealed differences across the student groups. The students in College $\mathrm{C}$, the low performing school with low tuition, came from more modest family backgrounds than students in the other schools. Only 11 percent of the students' fathers were professionals and 33 percent were businessmen. Father's educational level was lower among students from College C with 27 percent having a high school or vocational degree compared to 10 percent in College A, the high performing college. The students in College $\mathrm{C}$ were also less likely to have a relative who was a nurse abroad compared to students in College A. Another interesting difference is by gender. All of the women who participated in focus groups wanted to migrate, but only 76 percent of the men did.

\section{Methods}

We transcribed and analyzed the focus groups. Transcripts were coded by reading responses and then assigning a concept to each response, such as “family decision” or “school quality.” When the idea occurred again, the same label was applied so that the researchers could identify the idea across focus groups (Krueger 1998). After the coding, the coded responses were compared across the groups to examine whether the concepts came up in the different focus groups (Morgan 1997). Following Knodel (1993), we summarized each group’s discussion in response to each question in an overview grid in order to compare and contrast across groups. We focused on similarities and differences by the quality of the school and by the gender of the groups. 
Themes from the focus groups

\section{Studying nursing is a family decision}

One consistent theme across all the focus groups was that the decision to study nursing was a family decision, not an individual decision. In almost all cases, family members advised the students to study nursing because of the possibilities for international migration, which was viewed as a way to secure the family's wellbeing. This view is expressed by a female student in College A:

It was really my mom who pushed me to take up nursing. Because I myself didn't know what to take for college. And it was also the same. It was because my other aunts and uncles stay there in the states and they talk about stories about being in demand of nursing in the States.

Here is a similar view from a male student in College C:

The reason why I chose nursing is that my uncle is also a medical technologist in an airline and at the same time a US citizen. He is the one supporting me in my studies. So I have my finances, in terms of money. I also have my money. But at the same time, the main reason why I chose nursing just because of my uncle's decision, it's not my decision.

In some cases, the family's goal was to get as many members living abroad as possible. The students were anxious to join parents already abroad. One female student talked about how her mother tried to file a U.S. visa petition for her, but experienced a problem with the visa application because their last names were different. The family decided that the fastest way to get a visa was to have her study nursing for 4 years and then find a job in the U.S. Although the groups' consensus was that the decision to study nursing was a family one, some individual female students from Schools C and F emphasized that the decision was their personal decision.

Many of the participants did not want to practice nursing for their entire careers. They often talked about their desire to do nursing for a while, make and save money, and 
then return to the Philippines to open a business. Once the students had taken care of their families with the income they had earned, they would be able to pursue a career of their choice. A quote from a female participant in College A showed this attitude clearly:

But right now, I'm not seeing myself to be a nurse until I retire. Because... We're still young... we still have many things that we really, really like to do. ..I'm inclined in art in terms of music. I want to enter into school like that...(laughter)... I still want to put up a business.. I want to be a chef in a restaurant... I want to own a hotel and stuff like that.

The responses suggested that the students would be migrants who were target earners, meaning that they had a savings goal in mind, and then when it was achieved, they would return to the Philippines and pursue another career.

Some participants, men in College B, indicated that they wanted to eventually become doctors, and they viewed nursing as a way to meet that goal. A young woman at College A mentioned that she had originally wanted to be a doctor, but the tuition was too expensive, so she chose nursing instead. Her relatives had suggested that she use earnings from nursing to finance medical school.

\section{Choosing a nursing school}

The "mushrooming" of nursing schools in the early 2000s and the decreasing pass rates on the licensure exams created alarm among the nursing leaders in the Philippines. One solution that they were able to implement was to release the results of the licensure examinations by school. The pass rates were public information, calculated for all graduates, first-time test takers, and repeat test takers. National newspapers published them, and the pass rates could be found on various websites through Google searches. Nursing leaders hoped to get information out to prospective students and their parents so 
that parents could make wise decisions about where to send their children for nursing school (M. Lorenzo, personal communication, August 12, 2008).

Deans’ performances were evaluated by the pass rates. We often noticed a copy of the most recent pass rates sitting on the Dean's desk when we did interviews with them. Because of their importance, Deans had incentives to try to increase their nursing licensure examination pass rates. At the same time, students paid high tuition rates, and schools did not want to lose revenue. The schools we visited showed different responses to the incentives.

In the case of College A, pass rates were high because it was a highly selective university. College B solved the tension by admitting many students to the program, but then screening out weak students through a challenging qualifying exam at the end of the second year. Therefore, the weak students did not graduate and did not have a chance to take the exam as College B graduates. College C was family owned, and the founder of the College wanted it to be accessible to everybody regardless of family background. The College was trying to improve teaching quality and providing students with opportunities to improve their English as a way to increase their poor passing rates.

Did students act upon the pass rate information when selecting a school? In the case of the high performing school, students mentioned the high pass rate. Also, in the men's focus group in Tagbilaran, the students talked about their decision to attend College P instead of another college because College P had a better pass rate. However, in most of the focus group discussions, students said that they chose the school based on family members' recommendations. The following quote from a male at College $\mathrm{C}$ is typical—“ “I also asked my aunt and my uncle living abroad what they think about nursing 
school. They said (College C) is one of the good nursing schools here in Manila.” For College C, which had the relatively low pass rate, students said that they chose the college because of its convenient location and low tuition. Also, it was one of the few programs that accepted "second coursers," or people who had already completed a Bachelor's degree in another field. In the women's focus group for College C, they mentioned the international tie of the College to a nursing college in the U.S. The focus group discussions suggested that although a very good indicator of school quality was available, the information had not diffused to everybody. The students had relied more on the perceptions of family members to assess school quality than the publicly provided information.

\section{Perceptions about the migration process}

The nursing students were optimistic about their prospects to migrate. Their main sources of information were newspapers and other mass media and relatives who had migrated abroad. They were aware that it had become more difficult to obtain visas from the U.S. compared to earlier in the decade. The students had heard news through the media of the U.S. retrogression, or delays in processing visas. A typical statement comes from the male focus group in College P:

Yeah, I heard it too it's really tough to get in there (the U.S.). I have a cousin who's a nurse there too. He said it's really tough these days. I don't know - he said something about the economy, but I don't know what's the real reason that he said it's just really tough to get work there as a nurse.

In the men's focus group that took place in Tagbilaran, the participants discussed the difficulty of getting a position in a tertiary hospital. They expected that they would have to work as volunteers in the closest large city, Cebu. One participant talked about 
how a cousin would help him find a job in a tertiary hospital. The students indicated that they needed to have a personal connection to get a job.

Participants with relatives working as nurses abroad expected that the relatives would help them to get jobs when they were ready. The Philippines is a country where family ties are very important to get jobs and other opportunities. The nursing students believed that the U.S. and Canadian labor market would work the same way. They also talked about finding reputable agencies, with the help of their relatives.

Most of the students were aware of the exams that would be required to be eligible to migrate to the U.S. Their information was less reliable when it came to understanding how the job market worked and how the visa issuing process worked.

Students who attended College A were the best informed about how to obtain nursing employment abroad. They talked about their clinical instructors, who would share information about the process. They had accurate information about visa wait times. These students also had knowledgeable relatives abroad. In the men's group, they inferred that they would try to go illegally and then find work. The students from College $\mathrm{C}$ had vague notions about how the process worked. They had faith that if they worked hard, did well in the courses and did well on their exams, they would be able to migrate:

Interviewer: What are your plans to migrate abroad?

Several students, at the same time: Study hard.

Student A: Don’t forget to put God at the center of everything.

Student B: If it's His will, then it's His will.

Student C: Get grades. Study hard. Get grades. 
There was misinformation. One female participant from College B said that her father told her she could work in Singapore, and then no visa would be required to go to the U.S.

With the flow of nurses to the U.S. and U.K. declining, the numbers migrating to the Middle East increased. The focus group participants discussed the desirability of migrating to the Middle East. When asked the worst countries for Philippine nurses, the women's groups all mentioned the Middle Eastern countries, and in two groups, mentioned Saudi Arabia. Their information came from media reports that had discussed the abuse of female Philippine migrants.

From College B, women's focus group:

Student A (Speaking about working in Saudi Arabia): They are so different from our culture. They are so strict. We have some conflicts with the traditions. The treatment of Filipinos there. Filipino nurses there... believing that we're only domestic helpers or slaves... You see in Middle Eastern countries.

Interviewer: How do you know that?

Student A: From the news.

However, students who had relatives with experience in the Middle East had different views. Their relatives in the Middle East had told them that nurses were treated well, and the Middle East was a good option. For example, a female student at College C said, “Well, actually my uncle worked in Qatar. He said it's also a nice country to work there as a nurse.” In College B, the women discussed relatives who went to Saudi Arabia and Libya and then migrated to Chicago and Canada. With difficulty getting jobs in hospitals in the Philippines, the Middle East was viewed as an option to get hospital experience. In several of the groups, several participants mentioned plans to go to the Middle East because of lower requirements than other countries. The men's group in College C 
mentioned that a Clinical Instructor told them no experience was needed to go to the Middle East. However, many postings for nurses in the Middle East listed through POEA do require tertiary hospital experience.

Across the groups, there was discussion of how it was difficult to get to the US because of the visa issues and the U.S. economy. Canada was an attractive option because it was easier to bring family there, and it was accepting Philippine nurses. In reality, only 178 Philippine nurses migrated permanently and 523 migrated temporarily to Canada in 2008. The students underestimated the difficulties of migrating to developed countries. In some groups, the students focused on the medium- and long-term, mentioning that the population of Canada and the U.S. was ageing, so demand for nursing would be growing.

Relating the focus-group data to the economic models of brain drain and brain gain, the students were motivated to study nursing by the possibility of migration. The number of nursing graduates rose due to migration and fell when economic conditions in the U.S. lowered the demand for internationally-trained nurses. In 2008, the students we conversed with had decided to pursue nursing at the peak of the nursing boom. They perceived that they would be able to migrate, although they were aware of difficulties in doing so. Information was widely available about the quality of nursing school education, as indicated by the pass rates on the Philippine Nursing Licensure Examination. This information was used by recruiting agents and by students at the high quality schools, but did not seem to have diffused to students who attended the school with low pass rates. 


\section{Conclusions}

The case of nursing in the Philippines from 2002 to 2014 presented an interesting case study of brain gain because the Philippines was the world’s largest supplier of immigrant nurses. In addition, nursing colleges were primarily in the private sector. Increased demand for nursing school slots was readily accommodated through expansion of existing programs and the establishment of new schools and programs. The number of nursing graduates increased faster than the Philippine economy's ability to absorb them. By 2008, new graduates from nursing schools who passed the nursing exam were not able to find paying jobs in Philippine hospitals.

Enrollments and graduations from nursing school showed a cobweb pattern, as described by Schiff (2006). As the time required to process visas to the U.S. increased and U.S. demand for Philippine nurses fell, enrollments in nursing schools fell. The nurses who were able to migrate were those with experience and those who had trained in top-ranked schools.

One might describe the case of nurses in the Philippines in the 2000s as a speculative bubble. Students rushed into nursing programs when migration to the developed countries boomed in the early 2000s. However, demand abruptly shifted as developed country employers experienced recessions. Immigration policy was also capricious. Because of the time required to complete a degree and students' overoptimism about migration prospects, the Philippines went from a situation where people were writing about a nursing shortage in the mid 2000s to a situation of a nursing glut, where young nursing graduates had to pay to obtain necessary experience in tertiary 
hospitals. This was a costly strategy for families who invested in a nursing education as a way to achieve their economic dreams.

Migration policy in the Philippines might have resulted in a brain gain of nursing graduates, with more nursing graduates (and perhaps college graduates) than would have occurred in the absence of migration. However, a nursing degree requires specific courses that are of limited use in other professions. Future research might examine the occupations that Philippine nursing graduates pursued, whether families’ investments in education paid off, and whether nursing graduates were able to migrate. The press speculated that many graduates were working in call centers (Uy 2008). Salami, Nelson, Hawthorne, Muntaner, and McGillis Hall (2014) documented the migration of Philippine nurses to work as domestic workers in Canada. Following development policies that encourage migration might impose an unacceptable burden on middle-class and lower middle-class citizens, even if policies result in brain gain instead of brain drain. For brain gain to occur requires that families fail in their dreams of migrating to a developed country. 
Table 1. Philippine nursing colleges selected for focus groups, 2008.

\begin{tabular}{|c|c|c|c|c|c|c|}
\hline $\begin{array}{l}\text { School } \\
\text { classification }\end{array}$ & $\begin{array}{l}\text { School } \\
\text { label }\end{array}$ & Location & $\begin{array}{l}\text { Tuition } \\
\text { per } \\
\text { semester } \\
\text { php } \\
\text { (\$US } \\
\text { 2008) }\end{array}$ & $\begin{array}{l}\text { Total } \\
\text { number of } \\
\text { graduates } \\
\text { taking the } \\
\text { exam for } \\
\text { the first } \\
\text { time in } \\
2008\end{array}$ & $\begin{array}{l}\text { Pass } \\
\text { rate } \\
\text { first- } \\
\text { time } \\
\text { test } \\
\text { takers } \\
2008\end{array}$ & $\begin{array}{l}\text { Pass } \\
\text { rate } \\
\text { all } \\
\text { test } \\
\text { takers } \\
2008\end{array}$ \\
\hline $\begin{array}{l}\text { Outstanding } \\
\text { performance }\end{array}$ & $\mathrm{A}$ & Manila & $\begin{array}{l}56,000 \\
(\$ 1,281)\end{array}$ & 468 & $99 \%$ & $97 \%$ \\
\hline $\begin{array}{l}\text { Average } \\
\text { performance }\end{array}$ & B & Manila & $\begin{array}{l}56,000 \\
(\$ 1,281)\end{array}$ & 2417 & $78 \%$ & $69 \%$ \\
\hline $\begin{array}{l}\text { Low } \\
\text { performance }\end{array}$ & $\mathrm{C}$ & Manila & $\begin{array}{l}37,000 \\
(\$ 847)\end{array}$ & 1033 & $56 \%$ & $40 \%$ \\
\hline $\begin{array}{l}\text { Average } \\
\text { performance }\end{array}$ & $\mathrm{P}$ & $\begin{array}{l}\text { Tagbilaran, } \\
\text { Bohol }\end{array}$ & $\begin{array}{l}35,000 \\
(\$ 800)\end{array}$ & 373 & $69 \%$ & $62 \%$ \\
\hline
\end{tabular}

Source: Authors’ data and Professional Regulation Commission. 
Table 2. Characteristics of participants in the nursing student focus groups, Manila and

Tagbilaran, Philippines, 2008 (N=42).

\begin{tabular}{|c|c|}
\hline Characteristic & Mean/proportion \\
\hline Age & 22.85 (6.93 s.d) \\
\hline Female & 48.84 \\
\hline Male & 51.16 \\
\hline Married & 9.30 \\
\hline Single & 90.70 \\
\hline Nursing is first BS degree & 72.10 \\
\hline Nursing is second BS degree & 27.91 \\
\hline \multicolumn{2}{|l|}{ Mother’s education level } \\
\hline High school/vocational & 16.28 \\
\hline Bachelor's degree or higher & 83.72 \\
\hline \multicolumn{2}{|l|}{ Father's educational level } \\
\hline High school/vocational & 14.28 \\
\hline Bachelor's degree or higher & 85.72 \\
\hline \multicolumn{2}{|l|}{ Father's occupation } \\
\hline Seaman & 19.05 \\
\hline Professional & 48.65 \\
\hline Businessman & 16.22 \\
\hline Other (police officer, carpenter, electrician, etc.) & 16.08 \\
\hline Lived outside the Philippines & 13.95 \\
\hline Has at least one relative who lives outside the & 88.10 \\
\hline \multicolumn{2}{|l|}{ Philippines } \\
\hline \multicolumn{2}{|l|}{ Philippines } \\
\hline Has at least one relative who lives in the U.S. & 67.44 \\
\hline Has at least one relative who lives outside the & 32.56 \\
\hline \multicolumn{2}{|l|}{ Philippines and is a nurse } \\
\hline Intends to migrate & 88.10 \\
\hline \multicolumn{2}{|l|}{ Top country choice for migration } \\
\hline USA & 63.16 \\
\hline Canada & 23.68 \\
\hline UK & 13.15 \\
\hline New Zealand & 2.63 \\
\hline \multicolumn{2}{|l|}{$\begin{array}{l}\text { Who is funding education? (Could name more than } \\
\text { one person. } 39 \text { valid responses) }\end{array}$} \\
\hline Self & 15.38 \\
\hline Parents & 58.97 \\
\hline Siblings & 20.51 \\
\hline Other extended family members & 15.38 \\
\hline
\end{tabular}


Figure 1. Philippines nursing and medical and allied fields university enrollments and graduates, 2000—2014.

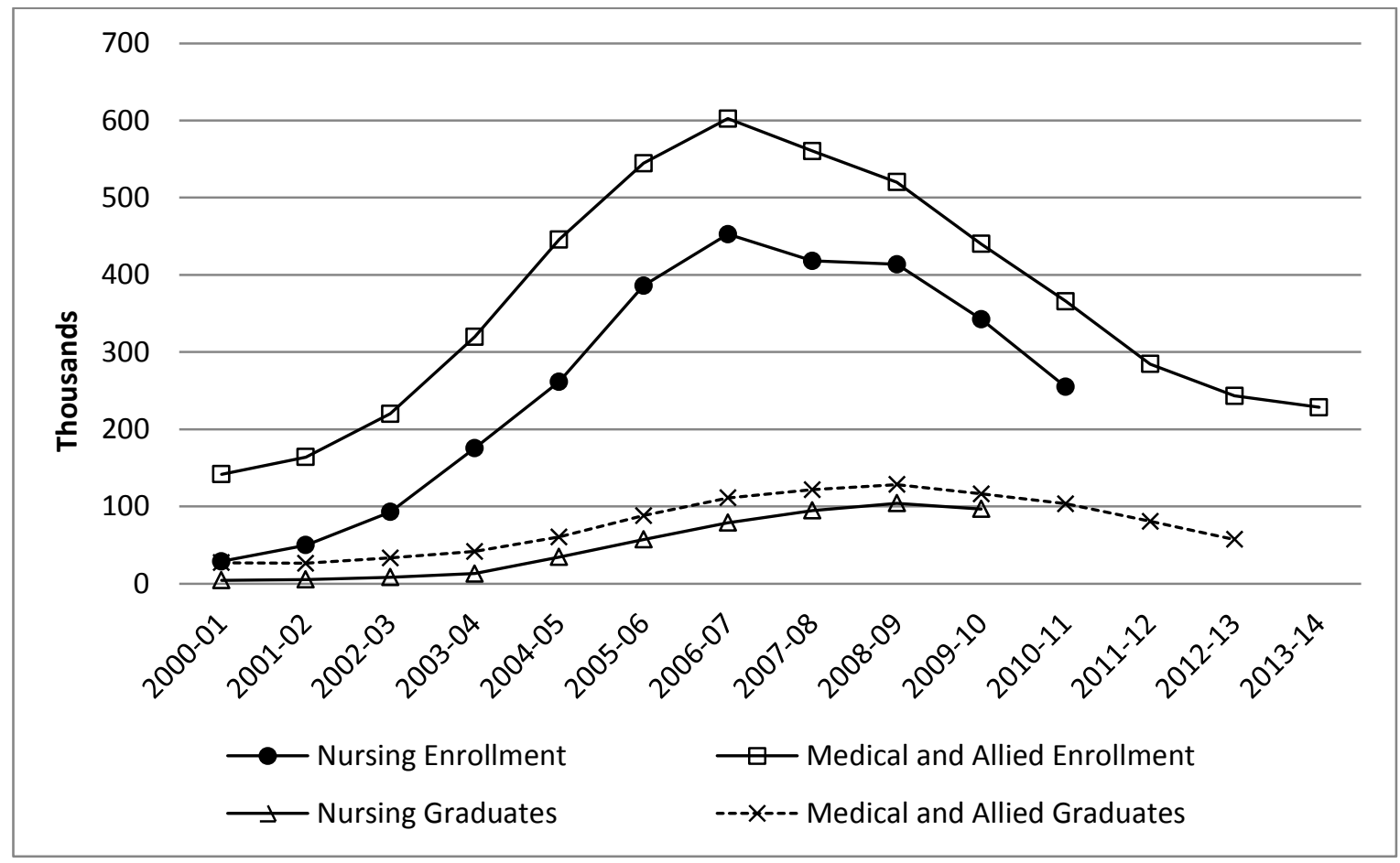

Sources: Lorenzo et al. 2012, Commission on Higher Education (CHED) 2014, Commission on Higher Education (CHED) 2012.

Figure 2. Philippine nursing licensure examination 2006—2014.

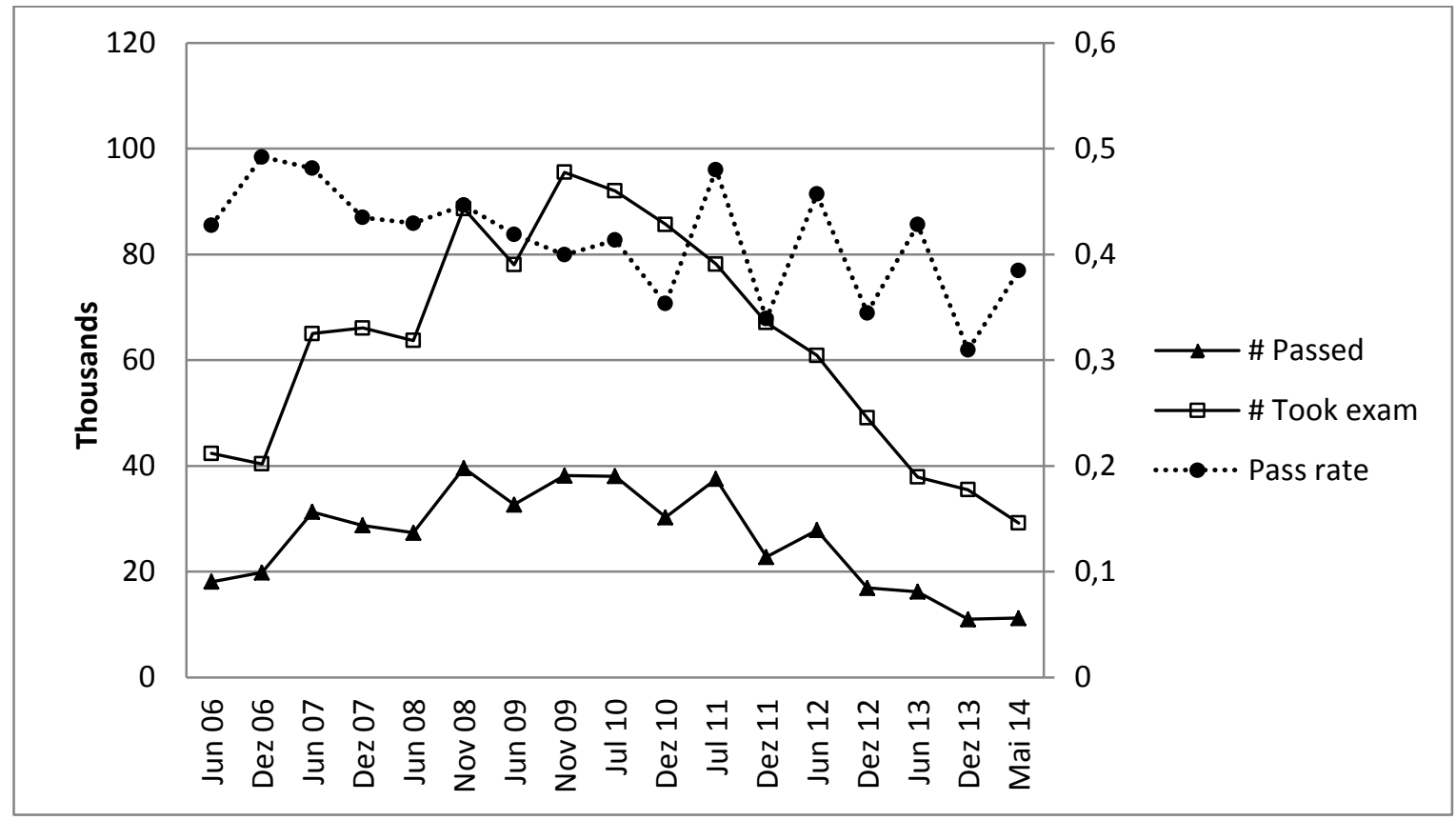

Source: Professional Regulation Commission, Government of the Philippines 
Figure 3. Real nursing wages in the Philippines, 2004-2012, in 2010 pesos per month.

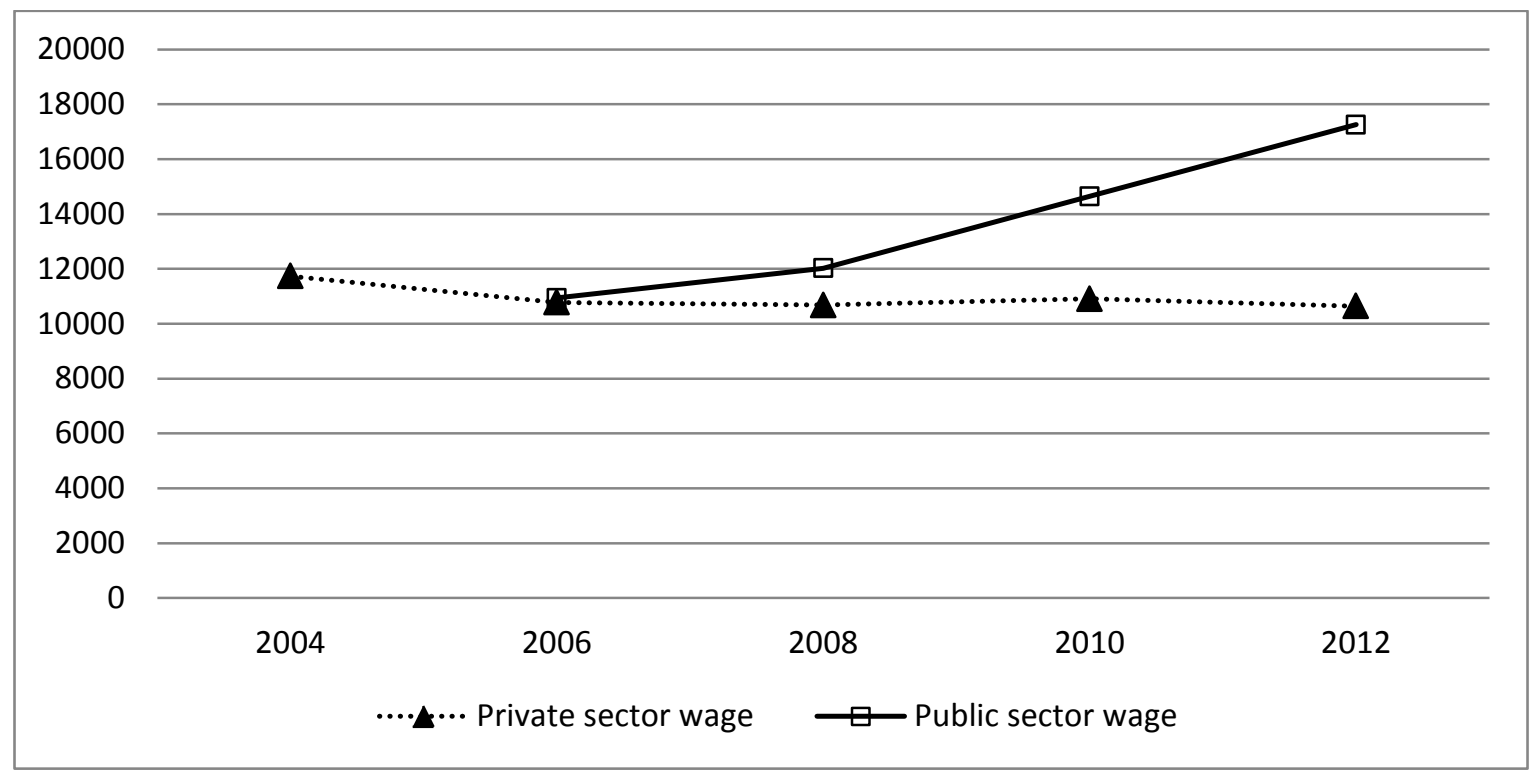

Source: Government of the Philippines, Yearbook of Labor Statistics; World Bank 2014.

Figure 4. Destination Countries for Philippine nurses, temporary migration, 1992—2010.

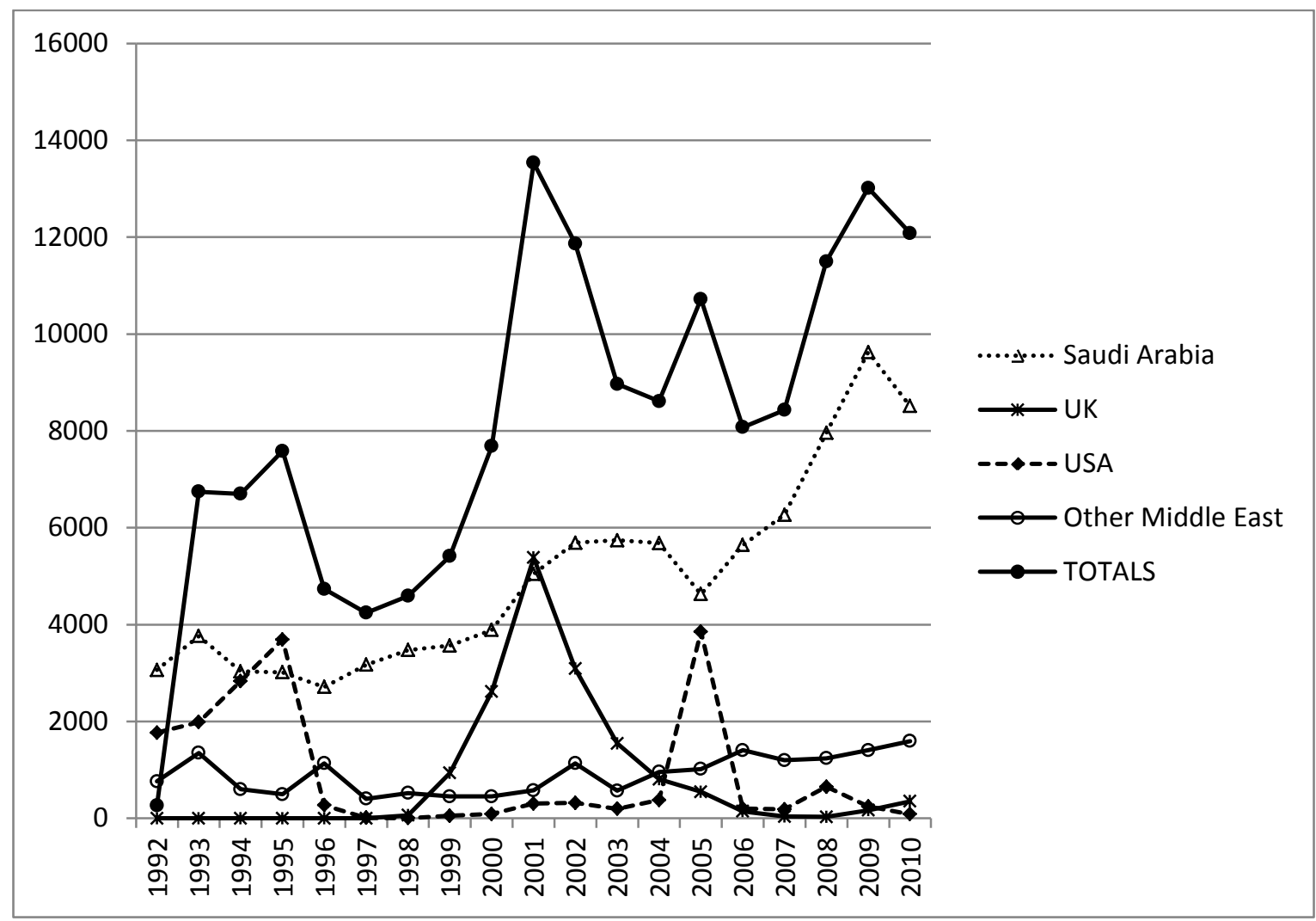

Source: Lorenzo et al. 2012 and POEA 2014. 
Figure 5. Permanent migration of Philippine nurses, 1997-2008.

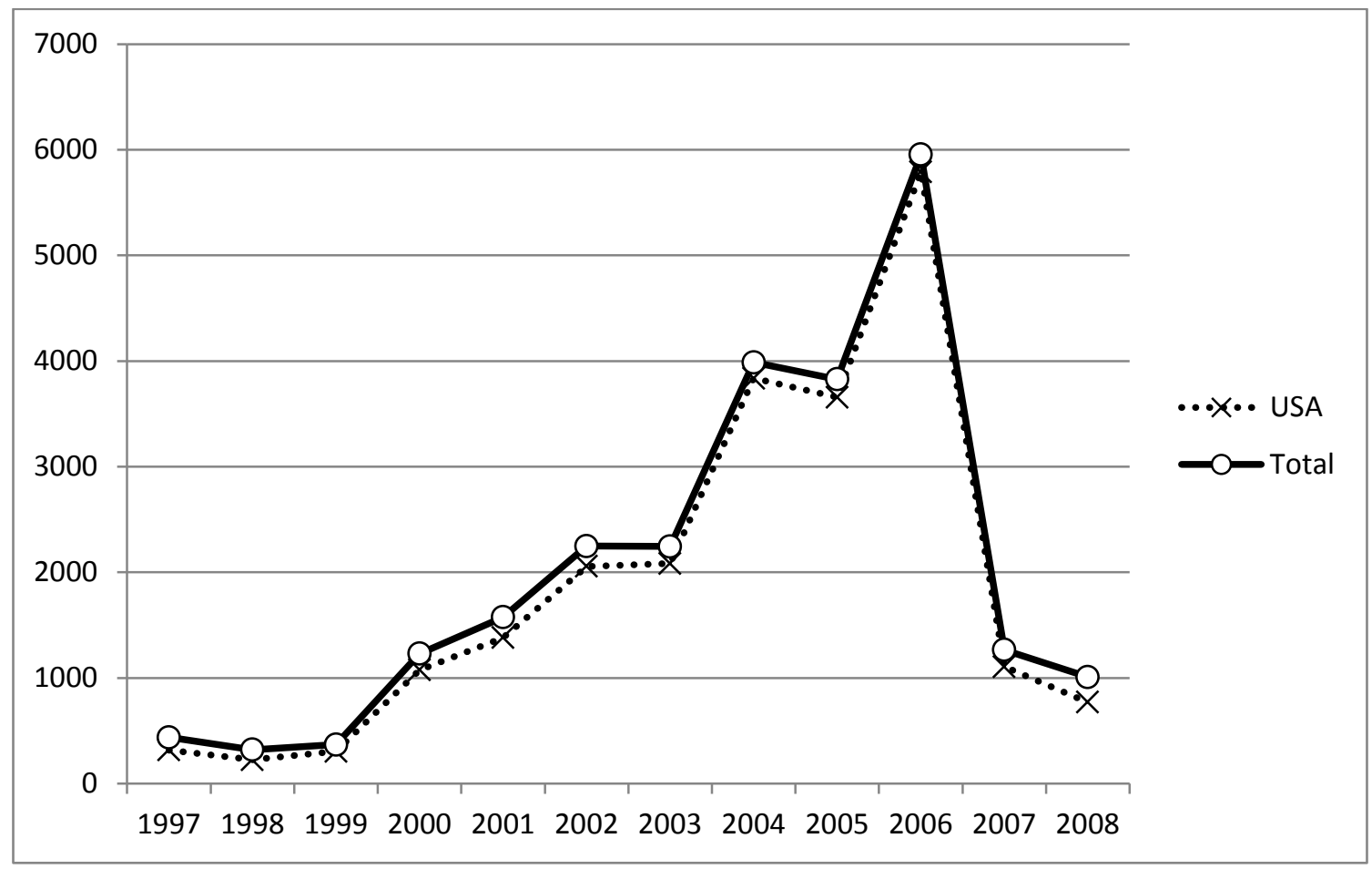

Source: Lorenzo et al. 2012, from CFO 2009 


\section{References}

Aiken, L., J. Buchan, J. Sochalski, B. Nichols, M. Powell 2004 “Trends in International Nurse Migration.” Health Affairs 23(3): 69-77.

Alave, K. 2009 "CHEd Urged to Name Inferior Nursing Schools." Philippine Daily Inquirer, November 2. Accessed January 14, 2015. http://newsinfo.inquirer.net/breakingnews/nation/view/20091102-233599/CHEdurged-to-name-inferior-nursing-schools

Aning, J. 2010 "More RP Nurses going to Britain." Philippine Daily Inquirer, June 14. Accessed January 14, 2015. http://newsinfo.inquirer.net/inquirerheadlines/nation/view/20100614275481/More-RP-nurses-going-to-Britain

Batista, C., A. Lacuesta, and P. Vicente 2012 "Testing the 'brain gain' hypothesis: Micro evidence from Cape Verde." Journal of Development Economics 97(1):32-45.

Beine, M., F. Docquier, and H. Rapoport 2008. "Brain Drain and Human Capital Formation in Developing Countries: Winners and Losers." Economic Journal 118(528): 631-652.

Brush, B. 2010 "The Potent Lever of Toil: Nursing Development and Exportation in the Postcolonial Philippines." American Journal of Public Health 100(9): 1572-1581.

Bureau of Labor and Employment Statistics, Republic of the Philippines 2013 Yearbook of Labor Statistics 2013 Manila, Philippines: BLES. Accessed January 14, 2015. http://www.bles.dole.gov.ph/PUBLICATIONS/Yearbook\%20of\%20Labor\%20St atistics/STATISTICAL\%20TABLES/PDF/CHAPTER\%209/Tab9.5.pdf

Bureau of Labor and Employment Statistics, Republic of the Philippines 2006 Yearbook of Labor Statistics 2006 Manila, Philippines: BLES.

Chand, S. and M. Clemens 2008 "Skilled Emigration and Skill Creation: A QuasiExperiment." Crawford School of Economics and Government, The Australian National University Working Paper 08-05.

Choy, C. C. 2003 Empire of Care: Nursing and Migration in Filipino American History. Durham, NC, Duke University Press.

Commander, S., M. Kangasniemi, and L.A. Winters 2004 "The Brain Drain: Curse or Boon? A Survey of the Literature." In Challenges to Globalization: Analyzing the Economics. Ed. R. E. Baldwin, and L. A. Winters, Chicago: University of Chicago Press, pp. 235-272.

Commission on Higher Education (CHED) 2011 "CHEd Memoradum Order No. 18 Subject: Amendments to Article XI-Sanctions of CMO No. 14, S. 2009 'Policies and Standards for Bachelor of Science in Nursing (BSN) Program'." Accessed January 14, 2015. http://www.ched.gov.ph/wp-content/uploads/2013/07/CMONo.18-s2011.pdf

Commission on Higher Education (CHED) 2014 "Higher Education Data: 2014."

Republic of the Philippines, Office of the President. Accessed November 3, 2014 at http://www.ched.gov.ph/wp-content/uploads/2014/temp/10-

03/home/Higher\%20Education\%20Data\%202014\%20-

\%20Public\%20and\%20Private\%20HEIs.pdf

Commission on Higher Education (CHED) 2014 "Higher Education Indicators as of July 24, 2012." Republic of the Philippines, Office of the President. Accessed 
November 3, 02014 at http://www.ched.gov.ph/wpcontent/uploads/2013/07/Higher-Education-Indicator-as-of-July-24-2012.pdf

Docquier, F, O. Lohest and A. Marfouk 2007 "Brain Drain in Developing Countries." The World Bank Economic Review 21(2): 193-218.

Docquier, F. and A. Marfouk 2005 "International Migration by Educational Attainment (1990-2000)-Release 1.1 World Bank Policy Research Working Paper 3382.

Docquier, F. and H. Rapaport 2012 "Globalization, Brain Drain, and Development. Journal of Economic Literature 50(3): 681-730.

Gibson, J. and D. McKenzie 2011 "The Microeconomic Determinants of Emigration and Return Migration of the Best and the Brightest: Evidence from the Pacific." Journal of Development Economics 95: 18-29.

Goode, A. 2009 "Global Economic Changes and the Commodification of Human Capital: Implications of Filipino Nurse Migration." East Asia 26(2): 113-131.

Home Office UK Border Agency 2008 "Overseas Qualified Nurses and Midwives." Accessed January 16, 2015. http://webarchive.nationalarchives.gov.uk/20081230092243/http://www.ukba.ho meoffice.gov.uk/workingintheuk/tier2/overseasqualifiednurses/

Kingma, M. 2006 Nurses on the Move: Migration and the Global Health Care Economy. Ithaca, NY, Cornell University Press.

Knodel, J. 1993 "The Design and Analysis of Focus Group Studies: A Practical Approach" In Successful Focus Groups: Advancing the State of the Art. Ed. D. Morgan Newbury Park, CA:Sage, pp. 35-50.

Krueger, R. 1998 Analyzing and Reporting Focus Group Results. Thousand Oaks, CA: SAGE Publications.

Lopez, R., V. Thomas and Y. Wang 1998 "Addressing the Education Puzzle: The Distribution of Education and Economic Reform." World Bank Policy Research Working Paper 2031.

Lorenzo, F. M., J. Galvez-Tan, K. Icamina, and L. Javier 2007 "Nurse Migration from a Source Country Perspective: Philippine Country Case Study." Health Services Research 42(3 Pt 2): 1406-1418.

Lorenzo, F. M. et al. 2012 Philippines: Mobility of Health Professionals. Manila, Philippines: Institute of Health Policy and Development Studies, National Institutes of Health, University of the Philippines Manila.

Marchiori, L., I. Shen, and F. Docquier 2013 "Brain Drain in Globalization: A General Equilibrium Analysis from the Sending Countries' Perspective." Economic Inquiry 51(2): 1582-1602.

Mesa, E. 2007 "Measuring Education Inequality in the Philippines." The Philippine Review of Economics. XLIV(2): 33-70.

Morgan, D. 1997 Focus Groups as Qualitative Research, Second Edition. Thousand Oaks, CA: SAGE Publications.

OECD 2014 "Government at a Glance 2011, VI. Compensation in Selected Public Sector Occupations. 26. Doctors' and Nurses' Salaries." Accessed December 2, 2014. http://www.oecd-ilibrary.org/sites/gov_glance-2011en/06/02/index.html?itemId=/content/chapter/gov_glance-2011-32-en

Pazzibugan, D 2013 "CHEd Has Enough Powers to Shut Down Substandard Schools, Says Valisno." Philippine Daily Inquirer. Accessed January 14, 2015. 
http://newsinfo.inquirer.net/431505/ched-has-enough-powers-to-shut-downsubstandard-schools-says-valisno

Philippine Daily Inquirer 2010 "No Takers for Nursing Jobs." Philippine Daily Inquirer, April 21. Accessed on January 14, 2015.

http://newsinfo.inquirer.net/inquirerheadlines/regions/view/20100421-

265722/No-takers-for-nursing-jobs

Philippine Overseas Employment Administration 2014. Overseas Employment Statistics. (Multiple years) Manila, Philippines. Accessed January 15, 2015.

http://www.poea.gov.ph/stats/statistics.html

Professional Regulation Commission, Republic of the Philippines 2014. "Nurse Licensure Examination Results." Various years.

Quismundo, T. 2010 "CHEd Halts New Course Offerings in Nursing, 4 Other Fields of Study." Philippine Daily Inquirer, November 12. Accessed January 14, 2015. http://newsinfo.inquirer.net/breakingnews/nation/view/20101112-302859/CHEdhalts-new-course-offerings-in-nursing-4-other-fields-of-study.

Salami, B., S. Nelson, L. Hawthorne, C. Muntaner, and L. McGillis Hall 2014. "Motivations of Nurses who Migrate to Canada as Domestic Workers." International Nursing Review 61: 479-486.

Schiff, M. 2006 "Brain Gain: Claims about Its Size and Impact on Welfare and Growth are Greatly Exaggerated."In International Migration, Remittances, and the Brain Drain. Ed. C. Ozden and M. Schiff. Washington, DC, The World Bank, pp. 201226.

Tsitouras, D.J. and M. Pabon Lopez 2009 "Flatlining: How the Reluctance to Embrace Immigrant Nurses is Mortally Wounding the U.S. Healthcare System." Social Science Research Network Working Paper. Accessed January 15, 2015 at http://ssrn.com/abstract=1434169.

U.S. Bureau of Labor Statistics 2014. "Occupational Employment and Wages May 2008, 29-1111 Registered Nurses." Accessed December 1, 2014. http://www.bls.gov/oes/2008/may/oes291111.htm

U.S. Department of Homeland Security 20092008 Yearbook of Immigration Statistics. Washington, DC: U.S. Department of Homeland Security, Office of Immigration Statistics. Accessed January 15, 2015 at http://www.dhs.gov/xlibrary/assets/statistics/yearbook/2008/ois_yb_2008.pdf

U.S. Department of State 2008 "Visa Bulletin for December 2008, Number 3, Volume IX." Washington, DC. Accessed January 15, 2015. http://travel.state.gov/content/visas/english/law-andpolicy/bulletin/2009/visa-bulletin-for-december-2008.html

Uy, V. 2008 "No Nurse Surplus, Only Unqualified Graduates--Recruiters." Inquirer.net., September 1. Accessed January 14, 2015. http:/globalnation.inquirer.net/news/news/view/20080901-158050/No-nursesurplus-only-unqualified-graduates--recruiters

World Bank 2014 "Consumer Price Index" Accessed January 14, 2015. http://data.worldbank.org/indicator/FP.CPI.TOTL?page $=4$

World Bank 2014 " Data: GNI per capita" Accessed Januar 16, 2015. http://data.worldbank.org/indicator/NY.GNP.PCAP.PP.CD?page=1 